\title{
DISTURBING THE FISCAL THEORY OF THE PRICE LEVEL: CAN IT FIT THE EU-15? ${ }^{(*)}$
}

\author{
António Afonso ${ }^{(* *)}$ \\ Department of Economics, Instituto Superior de Economia e Gestão, \\ Universidade Técnica de Lisboa, \\ R. Miguel Lúpi, 20, \\ 1249-078 Lisbon, Portugal
}

This version: January 2002

\begin{abstract}
With the fiscal theory of the price level (FTPL), Leeper-Sims-Woodford (LSW) argued that the government budget constraint plays a key role in determining the price level. Indeed, there could even be a dispute vis-à-vis the role of monetary policy in the formation of the price level. Apart from several theoretical criticisms, also addressed in the discussion given in this paper, the attempts to validate empirically the novel theory are, so far, rather sparse. Therefore, one of the purposes of this paper is to tentatively assess the possible empirical evidence, concerning the FTPL, for the EU-15 countries.
\end{abstract}

Keywords: Fiscal theory of the price level; fiscal policy; EU-15; panel data models

JEL classification: C23; E31; H63

\footnotetext{
(*) This paper was in some way inspired by the research conducted for the author's Ph.D. thesis. The author acknowledges comments from Jorge Santos. The usual disclaimer applies.

${ }^{(* *)}$ Tel.: +351 21392 2807; Fax: +351 21396 6407; e-mail: aafonso@ @iseg.utl.pt
} 


\section{Introduction}

The fiscal theory of price level (FTPL), developed by Leeper (1991), Sims (1994) and Woodford (1994, 1995), relates to an already well known discussion in the literature, about whether fiscal policy plays a role, as important as monetary policy, in determining the price level. There is also a connection to the controversy concerning the use of rules to determine the nominal interest rate, that, as mentioned by Sargent and Wallace (1975), leave the price level undetermined, therefore LSW argue that the government budget constraint is crucial for the price level determination. ${ }^{1}$

The main point behind the FTPL is indeed the idea that the price level is determined through the inter-temporal government budget constraint. That is, the price level adjusts in order to assure that the value of nominal government debt, divided by the price level, equals the real present value of future budget surpluses. In other words, the price level equals the ratio of nominal government liabilities to the present value of future budget surpluses in real terms.

This paper adds to the literature, by offering a critical discussion of the theory and by trying to assess the empirical evidence concerning the feasibility of the FTPL, for the EU-15 countries, with panel data estimations, using annual data for the period 19702001. To the author's knowledge this is the first empirical attempt to globally evaluate the relevance of the theory for that set of European countries and appears also to be, so far, the only investigation using a panel approach to test the FTPL.

The remaining of the paper is as follows. Section two reviews the FTPL, section three gives a critical assessment of the FTPL, section four tentatively evaluates the empirical evidence for the EU-15, and section five is the conclusion.

\footnotetext{
${ }^{1}$ According to Buiter (1999) the inspiring contribution is credited to Begg and Haque (1984), even if this is a less mentioned paper in the literature. As a matter of fact, and as Auernheimer and Contreras (1991) mention, "An understandable reason why the Begg and Haque results are not cited in any of the current literature is that they were published in a journal of limited audience. In fact, we became aware of the existence of the paper by merely coincidental conversation with one of the authors."
} 


\section{The fiscal theory of the price level set-up}

Underlying the work developed by LSW is the idea that for some combinations of fiscal and monetary policy, the price level is determined by the ratio between government nominal liabilities and the real present value of future government assets (budget surpluses). This is an important issue since central banks seem to be now less enthusiastic in using monetary rules for their monetary policy decisions. The implementation of such rules is usually regarded as an attempt to capture the visible historical relationship between money and prices.

Several presentations and critical discussions of the theory and of its assumptions are offered namely by McCallum (1999a, 1999b, 2001), Buiter (1998, 1999, 2001) and Bassetto (2001), while explanations of the theory can be found in Kocherlakota and Phelan (1999), Christiano and Fitzgerald (2000) and Carlstrom and Fuerst (2000). Concerning the empirical testing of the theory, the literature is rather small, but one can mention the papers of Canzoneri, Cumby and Diba (1997, 2000), Cochrane (1999) and Woodford (1999), Mélitz (2000) and Creel and Sterdyniak (2000). ${ }^{2}$

\subsection{Ricardian versus non-Ricardian regimes}

The set-up for the FTPL may be understood on the basis of the categorization of two types of fiscal regimes, the way is done for instance by Woodford (1995): Ricardian versus non-Ricardian regimes. Actually, this classification had already been used by Aiyagari and Gertler (1985) who maintained that in a non-Ricardian regime the Treasury does not commit itself to match completely, in the future, new public debt with future taxes, since some part of the new debt is to be financed through money, the opposite of what would happen in a Ricardian regime.

\footnotetext{
${ }^{2}$ The literature on the FTPL has increased substantially, rendering difficult an exercise of keeping up with all the incoming references on the topic. Nevertheless, one can mention additionally papers by Woodford (1996, 1998a, 1998b, 2001), Cochrane (1999, 2000, 2001) and Sims (1999). The use of the FTPL in an international framework is discussed by Woodford (1996), Sims (1997, 1999), Dupor (2000), Bergin (2000), Canzoneri, Cumby and Diba (2001), Andrés, Ballabriga and Vallés (2000) and Daniel (2001). Loyo (2000) addresses the inflationary episodes in Brazil using the FTPL while Sims (2001) makes a similar attempt to assess the consequences of dollarization in Mexico. Also in the context of the FTPL, Corsetti and Mackowiak (2000) discuss and relate the occurrence of currency devaluations to the existence of fiscal unbalances.
} 
Canzoneri and Diba (1996) use another terminology, already adopted by Sargent and Wallace (1981). While the Ricardian regime is tagged as a "regime of monetary predominance", since money demand and supply determine in this case the price level, the non-Ricardian regime is labelled "a regime of fiscal predominance," as prices are now endogenously determined from the government budget constraint.

In a regime where the monetary policy is independent (active), as in a Ricardian regime, the monetary authority determines the money stock and the price level through a money demand equation, based on the quantitative theory of money. The government is in this case required to attain primary budget surpluses, in order that its budget constraint is consistent with the price level resulting from the money demand equation. There is then, according to Leeper's (1991) terminology, a passive strategy from the Treasury and an active behaviour from the Central Bank.

In a non-Ricardian regime, where the Treasury decides autonomously the values of the budget deficit and of the public debt, the price level may be determined independently from the monetary authority. In this case, the Central Bank assumes a passive attitude, money supply is endogenous, and the price level is determined by the government budget constraint. ${ }^{3}$ The FTPL could then be appropriate if the government did not choose a passive fiscal policy, that is, when the budget surpluses are not adjusted endogenously in order that the budget constraint satisfies the price level implicit in the money demand function.

\subsection{The critics from the fiscal theory to the monetarist explanation}

The FTPL argues against the assumption, suggested namely by Friedman, that inflation is purely a monetary problem. For instance, Woodford (1995) questions the idea, keen to the quantitative theory of money, that the Central Bank should control the money stock in order to attain price level objectives. The proponents of the FTPL maintain that even if there is no change in money stock, fiscal policy may independently affect the price level and the inflation rate. This situation may arise either from the possibility that

\footnotetext{
${ }^{3}$ For instance Cochrane (2000) argues that the government budget constraint "will determine the price level no matter what the rest of the economy looks like (...)."
} 
the Central Bank does not control the money supply, or due to the hypothesis that inflation may not, in fact, be a monetary issue.

When there is an increase in the price level, there will be as a consequence the decline of the real value of the government liabilities, understood here as the pooled liabilities of both the Treasury and the Central Bank. These liabilities comprise therefore the stock of government debt, in possession of the public, and the stock of monetary base. As a result of the price level rise, there is a negative wealth effect through the reduction of the real value of the individuals applications, for instance in government debt. Hence, there may occur a decrease of aggregate demand, with prices adjusting aggregate demand and supply in the short run.

For instance, with a fixed money supply, the increase of the budget deficit may be accompanied by the rise of prices, allowing the decrease of the real value of public debt, in order to guarantee the fulfilment of the government budget constraint. Following the above reasoning, one may recall the weak correlation between money and prices since the start of the $80 \mathrm{~s}$, in most of the industrialized countries, with the progressive abandon of monetary aggregates as an intermediate objective of monetary policy. $^{4}$

Lets then consider the traditional relation of the quantitative theory of money, between money and income,

$$
M_{t} v_{t}=P_{t} y_{t}
$$

where $M$ is nominal money, $P$ is the price level, $y$ is real income and $v$ stands for the income-velocity of money. ${ }^{5}$ Assuming, for instance, that the income-velocity of money depends on the nominal interest rate, $v_{t}=v\left(i_{t}\right),{ }^{6}$

\footnotetext{
4 "Throughout the English-speaking world, at least, central bankers have abandoned the notion that any of the conventional monetary aggregates constitute a suitable intermediate target for monetary policy. This has resulted from the discovery that these aggregates no longer appear to have any very reliable relationship, at least in the short run, with the variables, such as inflation and real activity, about which policymakers actually care" (see Woodford (1998b)). The same point is made by Romer (2000): “(...) most central banks, including the U.S. Federal Reserve, now play little attention to monetary aggregates in conducting policy." Dwyer and Hafer (1999) review some of the latest evidence concerning the relationship between monetary growth and inflation.

${ }^{5}$ Naturally, the classic reference for the identity of the quantitative theory of money is Fisher (1911, p. 24-32).
} 


$$
M_{t}\left(i_{t}\right)^{b}=P_{t} y_{t}, \mathrm{~b}>0
$$

using logarithms and the real effective interest rate, $r$, with perfect prediction, it is possible to write

$$
\ln M_{t}=\ln P_{t}+\ln y_{t}-b\left[\ln r_{t}+\ln P_{t+1}-\ln P_{t}\right]
$$

For simplification sake, it is possible to assume that income, the money supply and the real interest rate are constant, and then we have the following difference equation for the price level

$$
\ln P_{t+1}-\ln (M / y)=\frac{1+b}{b}\left[\ln P_{t}-\ln (M / y)\right]-\ln r .
$$

Hence, according to the initial price level, there is an infinite number of possible trajectories for the previous equation. The usual solution is to assume/choose the initial price level obtained from

$$
\ln P_{0}=\ln (M / y)-\ln r,
$$

in order to ensure that the price equation does not lead to an explosive trajectory. One of the critics put forward by Woodford $(1994,1995)$, is that this choice for the initial price level has no support on economic theory and it is not derived, for instance, from some money demand function optimisation.

The point made by LSW is that if consumers are non-Ricardian, and in the context of a non-Ricardian fiscal regime, the wealth effects should show up through nominal government debt, with the government budget constraint being then used to determine a unique price level. Therefore, the proponents of the FTPL defend that the price level is indeed determined by the government budget constraint,

\footnotetext{
${ }^{6}$ A hypothesis used namely by Cochrane (1999) and Christiano and Fitzgerald (2000).
} 


$$
\frac{B_{t}}{P_{t}}=\sum_{s=0}^{\infty} \frac{s_{t+s}}{(1+r)^{s+1}}
$$

where $B_{t}$ stands for the government nominal liabilities in period $t$, including the stock of public debt (for simplicity one year securities) and monetary base; $s_{t}$ is the primary budget government surplus in period $t$, including seigniorage revenues, in real terms; $r$ is the real interest rate, assumed constant, and considering also the usual transversality condition

$$
\lim _{s \rightarrow \infty} \frac{B_{t+s}}{(1+r)^{s+1}}=0 .
$$

However, it is relevant to bear in mind that fiscal and monetary policy, directly or indirectly, both end up being responsible for the fulfilment of the government budget constraint. Equation (6) will be successfully met if the government adopts a nonRicardian fiscal policy, using Woodford's terminology. Therefore, after the government having arbitrarly chosen a sequence of fiscal balances, by choosing the level of public expenditures, the price level will adjust endogenously to ensure compliance with the budget constraint. In other words, if equation (6) is to be met for any value of price level, than fiscal policy must adjust passively (Leeper [1991]), in line with a Ricardian regime (Woodford [1995]).

\subsection{The price level fiscal theory approach}

For the presentation of the FTPL framework, lets assume a model of numerous and infinitely lived households that maximize an utility function with money as an argument. This type of money-in-the-utility-function (MIUF) model is inspired in Sidrauski (1967) and Brock (1975) and the utility function of the consumers, supposed to be additive, may be written as

$$
U\left(c_{t}, m_{t}\right)=(1-\sigma)^{-1} A_{1} c_{t}^{1-\sigma}+(1-\eta)^{-1} A_{2} m_{t}^{1-\eta}, \sigma>0 ; \eta>0
$$


where $c_{t}$ is consumption in real terms in period $t, m_{t}=M_{t} / P_{t}$, and $M$ is the nominal stock of money. ${ }^{7}$

The budget constraint for the households, in nominal terms, may be written as

$$
P_{t}\left(y-t x_{t}\right)=P_{t} c_{t}+M_{t+1}-M_{t}+\frac{B_{t+1}}{1+i_{t}}-B_{t}
$$

where $y$ is the output, assumed constant, $t x_{t}$ are the lump-sum taxes paid in $t, B_{t}$ stands for one period government debt securities, outstanding in period $t$, and $i$ is the nominal interest rate.

The previous constraint may also be presented in real terms as

$$
y-t x_{t}=c_{t}+\frac{M_{t+1}}{P_{t+1}} \frac{P_{t+1}}{P_{t}}-\frac{M_{t}}{P_{t}}+\frac{B_{t+1}}{P_{t+1}} \frac{P_{t+1}}{P_{t}} \frac{1}{1+i_{t}}-\frac{B_{t}}{P_{t}} .
$$

Defining $b_{t}=B_{t} / P_{t}$ and multiplying both members of the last equation by $\left(P_{t} / P_{t+1}\right)$, the utility optimization problem of the households is then given by

$$
\left\{\begin{array}{l}
\operatorname{Max} \mathrm{U}\left(\mathrm{c}_{\mathrm{t}}, m_{t}\right)=(1-\sigma)^{-1} A_{1} c_{t}^{1-\sigma}+(1-\eta)^{-1} A_{2} m_{t}{ }^{1-\eta} \\
\text { S. a } \quad\left(\mathrm{y}-\mathrm{tx}_{\mathrm{t}}\right) \frac{P_{t}}{P_{t+1}}=\frac{P_{t}}{P_{t+1}} c_{t}+m_{t+1}-\frac{P_{t}}{P_{t+1}} m_{t}+\frac{1}{1+i_{t}} b_{t+1}-\frac{P_{t}}{P_{t+1}} b_{t},
\end{array}\right.
$$

with the following first order condition for the optimum solution, assuming that $P_{t+1}^{e}=P_{t+1}$,

$$
U_{c}\left(c_{t}, m_{t}\right)=\frac{P_{t}}{P_{t+1}} \frac{1+i_{t+1}}{1+r} U_{c}\left(c_{t+1}, m_{t+1}\right),
$$

which is the usual Euler equation, now depicting addionally the use of money in the households utility function.

\footnotetext{
${ }^{7}$ The utility function used here (inspired in McCallum (1999a)) is basically a parametric version of the general formulations used by Leeper (1991) and Woodford (1995).
} 
The consolidated government budget constraint (including the Central Bank) is as follows,

$$
P_{t}\left(g_{t}-t x_{t}\right)=M_{t+1}-M_{t}+\frac{B_{t+1}}{1+i_{t}}-B_{t},
$$

with the budget deficit financed, either by the issuance of money, either by the issuance of public debt. $B_{t+1}$ are government bonds issued in period t, at price $1 /\left(1+i_{t}\right)$, to be reimbursed in period $t+1$ for one monetary unit, and $g_{t}$ and $t x_{t}$ are respectively the government expenditure and taxes in real terms, in period $t$. The budget constraints of the households and of the government imply the following equilibrium condition for the goods and services market in the economy, after adding (9) and (13),

$$
y=c_{t}+g_{t} .
$$

In real terms the government budget constraint can also be presented as

$$
g_{t}-t x_{t}=\frac{M_{t+1}}{P_{t+1}} \frac{P_{t+1}}{P_{t}}-\frac{M_{t}}{P_{t}}+\frac{B_{t+1}}{P_{t+1}} \frac{P_{t+1}}{P_{t}} \frac{1}{1+i_{t}}-\frac{B_{t}}{P_{t}}
$$

and, using once more the definitions $b_{t}=B_{t} / P_{t}$ and $m_{t}=M_{t} / P_{t}$, it is possible to write the government budget constraint as

$$
g_{t}-t x_{t}=m_{t+1} \frac{P_{t+1}}{P_{t}}-m_{t}+b_{t+1} \frac{P_{t+1}}{P_{t}} \frac{1}{1+i_{t}}-b_{t}
$$

By definition, the real interest rate is given by the Fisher relation,

$$
1+i_{t}=\left(1+r_{t}\right)\left(1+\pi_{t+1}^{e}\right)
$$

and supposing that the price level is correctly predicted for $t+1$, that is, assuming perfect forecast for the expected inflation rate, $\pi_{t+1}^{e}\left(\right.$ with $\left.P_{t+1}^{e}=P_{t+1}\right)$,

$$
\pi_{t+1}^{e}=\pi_{t+1}=\frac{P_{t+1}-P_{t}}{P_{t}}
$$


this allows us to write

$$
1+i_{t}=\left(1+r_{t}\right) \frac{P_{t+1}}{P_{t}}
$$

Bringing to mind the situation mentioned above, where the monetary base growth rate is constant, and substituting the inverse of (19) in (16), results in

$$
\begin{aligned}
& b_{t+1} \frac{P_{t+1}}{P_{t}} \frac{1}{1+r_{t}} \frac{P_{t}}{P_{t+1}}=b_{t}+g_{t}-t x_{t} \\
& b_{t+1}=\left(1+r_{t}\right) b_{t}+\left(1+r_{t}\right)\left(g_{t}-t x_{t}\right) .
\end{aligned}
$$

Assuming also the hypothesis of a constant real interest rate, and for simplicity, if the budget deficit is stable, $\left(g_{t}-t x_{t}\right)=(g-t x)$, we have also

$$
b_{t+1}=(1+r) b_{t}+(1+r)(g-t x) \text {. }
$$

From the the last expression, it becomes clear that $b_{t}=B_{t} / P_{t}$ will follow an explosive trajectory since $(1+r)>0$. Notice also that from equation (22), the growth rate of government debt is given by the following difference equation

$$
\frac{b_{t+1}}{b_{t}}=(1+r)\left(1-\frac{s}{b_{t}}\right)
$$

where the primary budget surplus, $s$, is given by $s=t x$ - $g$, and that eventually (23) converges to $(1+r)$ while $b$ increases. However, in this case, the government is conducting Ponzi games, and it would no be possible to satisfy a transversality condition such as the one given by equation (7).

An explosive situation for the stock of real government debt will be avoided if the initial value for $b$ is

$$
b_{0}=-(1+r)(g-t x) / r \text {, }
$$

in order to ensure that $b$ remains constant at that same value. As a matter of fact, with that initial value for $b$ one gets simply 


$$
\frac{B_{t}}{P_{t}}=\left(\frac{1+r}{r}\right)(t x-g) .
$$

Therefore, according to the FTPL, $P_{0}$ is determined by the previous expressions and is given by

$$
P_{0}=r B_{0} /[(1+r)(t x-g)]
$$

in other words, the price level is endogenously determined from the ratio between the initial public debt level and the government balance. It is therefore somehow understandable why Sims (1997, p. 8) labels this approach as "'quantity theory of [public] debt" determination of the price level."

\section{A critical discussion of the fiscal theory}

In a Ricardian regime, of monetary dominance, the nominal value of government debt (or in a broader sense the government liabilities) results from the accumulation of budget deficits. If the price level is determined by the quantitative theory of money, the real value for the stock of public debt comes out endgenously and the present value of future budget surpluses must adjust in order to meet the government budget constraint.

In the case of a non-Ricardian regime, of fiscal dominance, the real value of the stock of public debt is determined by the present value of future budget surpluses, and the price level that must adjust to gurantee the fulfilment of the budget government constraint. What we have here is then two different interpretations on how the adjustment of the several variables takes place in the framework of the government budget constraint. For instance, Cochrane (2001) maintains that Ricardian regimes are backward-looking, in the sense that the real values of the stock of public debt is determined by the price level and by past budget deficits, while a non-Ricardian regime is forward-looking, since it is now the real value of the stock of public debt, set accordingly with the present value of future budget surpluses, that will determine the price level.

Price level indetermination is directly related to the fact that the Central Bank may use monetary policy to determine the nominal interest rate. In this case, with the nominal 
interest rate set exogenously by the monetary authority, the equation of the quantitative theory of money, equation (1), and the equation for the price level change, equation (19), are used to determine the money stock and the price level (assuming a constant real interest rate). However, equation (19) only determines the inflation rate and not the price level, that is, $P_{t}$ is undetermined. In this situation, the relation of the quantitative theory of money determines the money stock in a passive way, which adjusts to the desired interest rate level, but it is unable to determine the price level. This undetermination may be solved through the government budget constraint, equation (6), that now determines the price level, the solution forwarded by the proponents of the FTPL. ${ }^{8}$

As an alternative, if the monetary authority decides to determine the money supply, then, in a Ricardian regime, of monetary dominance, equations (1) and (19) may determine with no further problems the price level and the nominal interest rate. In this case, the government budget constraint is always satisfied and will not be used to determine the price level. Also, if the Central Bank tries to set an objective for the money supply, when the government is carrying out an active fiscal policy, that is, a non-Ricardian regime, the price level may be overdetermined.

Indeed, one of the results of the monetarist theory is that the use of rules to determine the interest rate ends up in an indeterminacy for the price level, and the Central Bank may eventually loose control of the inflation rate. In fact, in this case, money supply is hopeless to uniquely determine the price level. The classic text is Sargent and Wallace (1975), where it is shown that price level is indeterminate when an interest rate rule is used and when prices are flexible. A clear exposition of this point is given namely by Blanchard and Fischer (1989, p. 577-582), but the issue can be tracked back to Wicksell (1965 [1898], 1907). Table 1 tries to summarise these ideas.

\footnotetext{
${ }^{8}$ Schmitt-Grohé and Uribe (2000) and Carlstrom and Fuerst (2001) discuss the issue of nominal and real indeterminacy in MIUF models while Bénassy (200) revisits the issue of price level indeterminacy when there is in place an interest rate rule.
} 
Table 1 - Fiscal determination of price level and monetary policy

\begin{tabular}{|l|l|l|}
\hline \multirow{2}{*}{} & \multicolumn{2}{|c|}{ The monetary authority tries to set: } \\
\cline { 2 - 3 } $\begin{array}{l}\text { Ricardian regime, } \\
\text { monetary dominance }\end{array}$ & $\begin{array}{l}\text { In this case the price level } \\
\text { is undetermined }(*)\end{array}$ & $\begin{array}{l}\text { The price level is } \\
\text { determined, using the } \\
\text { quantitative relation of } \\
\text { money }\end{array}$ \\
\hline $\begin{array}{l}\text { Non-Ricardian regime, } \\
\text { fiscal dominance }\end{array}$ & $\begin{array}{l}\text { The price level may be } \\
\text { determined by the } \\
\text { government budget } \\
\text { constraint }(* *)\end{array}$ & $\begin{array}{l}\text { The price level is } \\
\text { overdetermined }\end{array}$ \\
\hline
\end{tabular}

(*) The case mentioned by Sargent and Wallace (1975).

(**) Leeper (1991), Sims (1994) and Woodford $(1994,1995)$.

Buiter $(1998,1999,2001)$, one of the critics of the FTPL, argues that the theory proposed by the work of LSW is what he calls "the pure fiscal theory of the initial price level" (Buiter [1998, pp. 25]). In fact, Buiter (1998) mentions that the initial price level is determined by equation (25) and is proportional to the stock of non-monetary liabilities (public debt), and this could be understood strictly as what the author mentions as the "quantity theory of nominal bonds." However, and taking into account the initial price level, in the following periods prices will be determined by equation (19). Besides, the nominal stock of money has an effect on the nominal interest rate, that is, for a given level of public debt and prices, an increase of the money stock implies a decrease of the nominal interest rate and, with a constant real interest rate, there should be a decrease of the future nominal value of government debt. The decline of public debt will then lower the price level, and so Buiter maintains that money still influences prices.

Buiter stresses also the fact that it does not seem reasonable that the government uses the budget constraint (6) to determine the primary balance and the issuance of public debt, without taking into account a given price level. Also, the models presented by the proponents of the FTPL, give the impression that they are determining a level of public debt default and not so much the price level. If the responsibles of economic policy were to adopt the ideas of the FTPL, there would end up to appear either situations of default on public debt reimbursements or situations of hyperinflation.

Cochrane (2000) answers back to Buiter's criticisms by saying that Buiter is taking for granted a Walrasian formation of prices in the market, were no transaction occurs until 
the adequate price level is met, in order to validate the budget constraint. However, and since it is not possible to know beforehand which is that price level, nothing will prevent the government of deciding the indebtedness level and the primary balance that it wishes to assume. If the government did behave like Buiter seems to be suggesting, disregarding market restrictions, the level of public debt might rise without limit when, in fact, the equilibrium price level is adjusted to prevent that such boundless increase of government debt might occur.

Cushing (1999) argues that in a non-Ricardian regime, chacterized by an active fiscal policy, the fiscal determination of the price level requires some rather implausible assumptions. For instance, in order to determine the price level through the intertemporal budget constraint, it is necessary for the consumers to believe that the government will honour its debts, even when the stock of public debt rises to very high levels. If there is a significant risk that those debts are not paid, the government may have to change the way it conducts fiscal policy, to ensure that its intertemporal budget constraint is not violated, since the alternative, a price level increase, would reduce the real value of debt to be reimbursed to the public, that might not buy, in the future, new government debt in the market. In these circumstances, the price level would not be determined by the government budget constraint, instead, the price level ends up being a restriction to which that constraint must obey. Cushing (1999), as well as McCallum (1999a), criticise therefore the FTPL supposition of the transversality condition and the hypothesis that the stock of public debt is on a convergence path. In a non-Ricardian regime, neither the government nor the Central Bank are committed to ensure that convergence process, however, the public is supposed to believe that the government will not default in the future on its liabilities.

The essence of the FTPL, in its criticism of the quantitative theory of money, does not seem to be to figure out if the quantitative equation of money links or not the price level with the stock of money, but really to discuss if the stock of money and the price level may be determined by fiscal policy. However, to distinguish between if the supply of money and the interest rate are determined by fiscal policy or if the money supply and interest rate are determined exogenously, it is not an easy point to assess only under theoretical grounds. 
In empirical terms, there appears to be some evidence that could be read as being for and against the FTPL. For instance, the well known cases of hyperinflation in Europe in the beginning of the $20^{\text {th }}$ century, discussed by Cagan (1956) and by Sargent (1982), seem to indicate that the inflationary periods of Germany, Austria, Hungary and Poland were only surpassed after the problems in terms of fiscal deficits had been delt with. When studying the monetary characteristics of hyperinflations in Austria, Hungary, Poland and Russia in the 20s and in Greece, Hungary and Russia in the 40s, Cagan (1956) used models for money demand based on the strong relation existing between money and inflation. ${ }^{9}$

Loyo (2000) explains the hyperinflation of Brazil in 1975-1985 as a result a of a vicious circle between the nominal growth of government debt and the corresponding rollover of existing debt. Also, Woodford (1999, pp. 393) maintains that fiscal policy in the US might have been non-Ricardian before 1951: "That period would represent a historical example of the kind of interest-rate pegging regime for which the theory was developed."10

In the first half of the $70 \mathrm{~s}$, the idea of a regime of fiscal dominance, Ricardian in Woodford's terminology, may be relevant, since there was a decline of fiscal balances and an increase of inflation, namely in Italy and in the UK, see figures 1, 2 and 3. Also, and as mentioned by Sargent (1987), the fact that the government budget constraint is pratically absent from macroeconomic models in the 60s and 70s, may be an indication that the budget constraint was then seen more like an equilibrium condition and less as constraint.

In the beginning of the 80 s there was an increase of budget deficits in several western economies. According to the assumptions of the FTPL, there should have been a price level rise in order to reduce the government liabilities in real terms. For instance, in Italy, see Figure 2, there was a decline of inflation throughout the $80 \mathrm{~s}$, what seems to disagree with the FTPL. This is even more visible in the case of Germany, see Figure 1.

\footnotetext{
${ }^{9}$ A posteriori, the econometric problems of those models were pointed out namely by McCallum (1989).

${ }^{10}$ It was in March 1951 that was made the accord between the US Treasury and the Central Bank in order to give the Central Bank more autonomy to change interest rates, Hetzel and Leach (2001) give a reading of the implications of that agreement.
} 
Figure 1 - General government balance and inflation: Germany

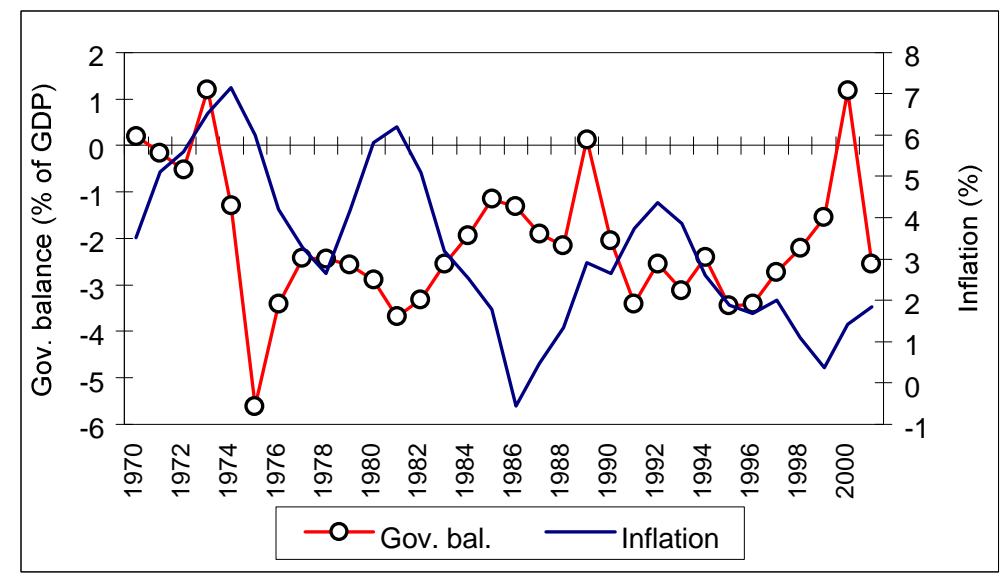

Source: European Economy 72, 2001. European Commission.

Figure 2 - General government balance and inflation: Italy

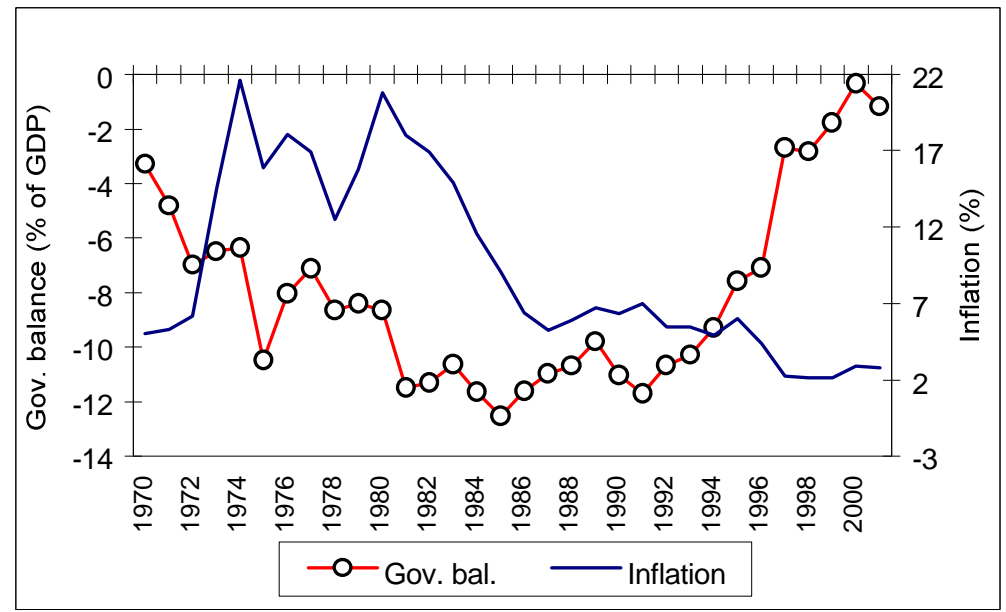

Source: European Economy 72, 2001. European Commission.

Figure 3 - General government balance and inflation: UK

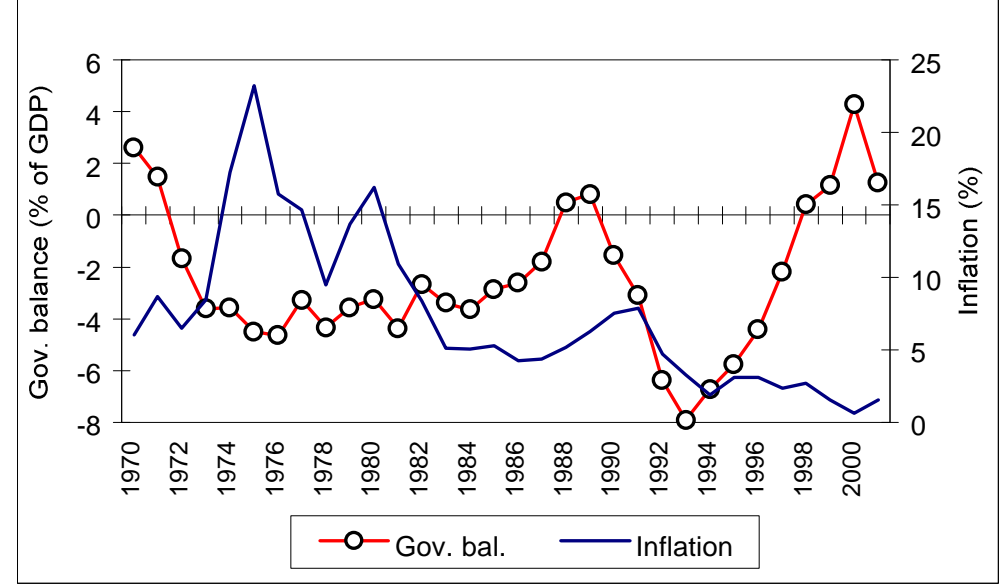

Source: European Economy 72, 2001. European Commission. 
This sort of interpretations is rejected by Cochrane (1999) who tries to reconcile these data with the FTPL, arguing that real primary deficits determined inflation, since after the middle of the 80 s there were improved expectations concerning future budget surpluses. Hence, when there are changes in the expectations about the level of future budget balances, the present value of fiscal balances is also adjusted, and this must be reflected on the change of the government liabilities, through price level changes. Therefore, with this reasoning, it is interesting to mention that in the $90 \mathrm{~s}$, at the same time that the US budget deficit declined, becoming even a surplus after 1998, it was possible to see a sustained decrease of the inflation rate.

Also, it is also relevant to distinguish between the money measure included in the equation of the quantitative theory of money and the monetary liability used in the government budget constraint. Indeed, in the equation of the quantitative theory of money, for instance equation (1), money is seen as a broader monetary aggregate (M1, M2 or even M3) than the monetary base used to to quantify the seigniorage revenues in the government budget constraint, equation (6).

Assume, for example, that the monetary authority reduces the money supply. If there is a Ricardian regime, of monetary dominance, the decrease of money supply should result in a drop of the price level. Notice also that this price level decline will bring about an increase of the real value of the outstanding stock of public debt, and, in the future, the government will have either to raise taxes or to cut public expenditures, in order to meet the budget constraint.

If there is a non-Ricardian regime, of fiscal dominance, a decrease in the money supply dose not affect the price level since this variable is now determined through equation (25). However, the equilibrium price level should now be smaller than the one that was in place previously to the money supply cut, in other words, there might be too much inflation. This situation would be possible if the government did not obey, for some time, its budget constraint. The budget constraint would then only be fulfilled for a long-run equilibrium situation, which seems to be a rather strong assumption. As a matter of fact, the government budget constraint is, by construction, an identity that should hold at any point in time. Eventually, if for instance the reduction of money supply was associated to a tax raise, then the money supply decrease would end up in a 
price level fall, either through money demand, based on the quantitative theory of money, where prices decrease on a one to one basis with the change of money stock, either through equation (25).

The main feature of the government budget constraint, the fact that public debt can not go beyond the value of present and future budget surpluses, should be met, either in equilibrium or not. This characteristic of the government constraint does not seem to be adopted by the proponents of the FTPL, who assume that the budget constraint must be fulfilled only in equilibrium, a hypothesis that is hard to sustain. See for example the comments forwarded by Woodford (1998a, p. 17-18)):

"Note that our argument does not involve any denial that the value of the public debt must actually equal the present value of future government budget surpluses, in equilibrium. What we deny is that condition (1.14) [the initial value of public debt is equal to the present value of current and future budget surpluses plus seigniorage] is a constraint upon government fiscal policy, that must be expected to hold regardless of the evolution of goods prices and asset prices. Instead of a "government budget constraint", the condition is properly viewed as an equilibrium condition, that follows from the joint requirements of private sector optimisation and market clearing." 11

Still another point assumed by the FTPL is also open to criticism: the assumption that the government allways intends to rollover a fraction of the outstanding stock of public debt. However, if the successive budget surpluses allow to significantly reduce the stock of public debt, the hypothesis that the price level is determined by the intertemporal government budget constraint, equation (6), implies that the price level would approach zero. Notice that some of the EU-15 countries (for instance Ireland, Denmark, Finland, United Kingdom) countries and the US, had in the last years consecutive budget surpluses, resulting in the reduction of the stock of public debt, without significant changes in the inflation rate.

Additionally, a contribution for an increase of inflation might be the occurrence of defaults on interest rate payments and reimbursements of public debt. These situations may then reduce the present value of future budget surpluses and the price level would

\footnotetext{
${ }^{11}$ Still on the budget constraint, it does not seem clear the idea forwarded by Cochrane (2000) that sees the constraint not as a restriction but like a "government valuation equation."
} 
then have to rise to ensure once more the fulfilment of the intertemporal government budget constraint. ${ }^{12}$

\section{Validation of the fiscal theory of the price level}

Regarding the empirical validation of the FTPL, Cochrane (1999) doubts of the interest of that validation, that is, of the interest in assessing empirically the suitability of a nonRicardian regime, since the causal relations between the several variables can never be rejected/accepted without making use of additional assumptions, frequently stemming from the hypothesis itself made about the fiscal regime that is tested. It seems however that this is also true with the identity of the quantitative theory of money and the resulting money demand functions.

For example, Woodford (1995) also contends that it does no make much sense to test in empirical terms the FTPL. The line of reasoning provided is based on the idea that all monetary regimes, monetary rules ourmoney demand specifications leave the price level undetermined, and consequently the price level can only be determined by the fiscal policy. $^{13}$

The solution of trying to validate the FTPL through the inspection of budget deficits and government debt, a possible empirical approach, is not easy since in a non-Ricardian regime there is solely the guarantee that the government budget constraint is obeyed in equilibrium (see Cochrane [1999] and Woodford [1998a]). This conviction is also criticised by Buiter (1999) who says that “...the government's intertemporal budget constraint is a constraint on the government's instruments that must be satisfied for all admissible values of the economy-wide endogenous variables."

The government budget constraint, equation (6), and the usual transversality condition, equation (7), may give a suggestion on how to assess the adjustment process of the main fiscal variables. A possible method would be to try to understand wether is the price

\footnotetext{
${ }^{12}$ Kenc, Perraudin and Vitale (2000) mention this point.

${ }^{13}$ Korcherlakota and Phelan (1999) are also sceptical as to the feasibility of the empirical validation of the FTPL.
} 
level that adjusts to the future fiscal surpluses, or if it is the trajectory of fiscal surpluses that adjusts to the price level.

In a Ricardian regime, it is assumed that government debt is not seen as wealth, and that the public takes for granted that the government eventually will adjust its strategy to be consistent with the transversality condition and fiscal policy sustainability. It is nevertheless possible that in some periods, the budget surpluses do not seem adequate to keep the debt-to-GDP ratio under acceptable limits. However, even in that circumstance, there might not be a price level increase.

In a non-Ricardian regime it is expected that the transversality condition be met in equilibrium, and that the stock of public debt may temporarily show values that are inconsistent with such a condition. In this case, even if the debt-to-GDP ratio is rather high, and if there is a wealth effect from government debt, there might be an increase of aggregate demand resulting in the rise of the price level. The real value of the government liabilities would then be reduced, allowing once more the formation of favourable expectations as to the fulfilment of the transversality condition.

\subsection{Budget deficits and public debt}

Canzoneri, Cumby and Diba (2000) use a bivariate VAR test for the existence of a Ricardian regime, by assessing if the primary budget surplus, as a percentage of GDP, negatively influences the government liabilities, also as a ratio of GDP. In the government liabilities are included both public debt and monetary base. In a regime of monetary dominance, a Ricardian regime, the positive changes in the budget surplus should be used to pay back some of the outstanding public debt, that is, one would expect to see an inverse relationship between the primary budget surplus and the government liabilities. They test a VAR model using the primary budget surplus, in real terms, as a percentage of GDP, including seigniorage revenues and the government liabilities, in real terms, as a percentage of GDP, including public debt and monetary base.

In such a set-up, the hypothesis of a Ricardian regime, of monetary dominance, could not be rejected when the increase of budget surpluses is used to cut down government 
debt. If, however, higher budget surpluses are associated with higher public debt, then it is possible that there is in place a non-Ricardian regime, that is, a regime of fiscal dominance. Still another test for the validation of the FTPL is to assess if the budget surplus does not react systematically to the level of public debt. Then, the price level could be determined by the government budget constraint, and not by money demand and money supply. In this case, the price level may change to adjust the real value of the stock of public debt to the present value of the future primary budget surplus. If, however, one observes that the government tries to increase the budget surpluses in order to diminish the existing stock of public debt and comply with the budget constraint.

With annual data for the US, for the period 1951-1995, Canzoneri, Cumby and Diba (2000) mention that positive shocks in the primary budget surplus, decrease the real value of the stock of public debt, and therefore they conclude for the existence of Ricardian regime, with the Treasury assuming a passive strategy and the Central Bank assuming an active strategy. Also, Canzoneri, Cumby and Diba (1997) mention that it does not seem to be any empirical evidence concerning the existence of a regime of fiscal dominance in the OECD countries.

Cochrane (1999) uses also a VAR model, with a single lag, with the following variables: public debt as a percentage of private consumption, the budget surplus-private consumption ratio, the consumption rate growth and the real interest rate implicit in the stock of public debt. With annual data for the US, for the period 1960-1996, they conclude that positive changes in the budget surplus reduce the stock of public debt, a result similar to the one reported by Canzoneri, Cumby and Diba (2000). Woodford (1999) reaches the same conclusions as Cochrane (1999), with the same data and variables, with the exception that the real interest rate is discarded, on the basis that it should be implicit in the evolution of the other three variables (see Woodford [1999]). ${ }^{14}$

Other empirical work, that relate to this discussion, is provided by Debrun and Wyplosz (1999) and Mélitz (2000) who estimate reaction functions respectively for the UE-12 and OECD countries, in order to evaluate if the primary budget surplus responds

\footnotetext{
${ }^{14}$ Indeed, Cochrane (1998) mentions that the estimations of the equations for the real interest rate and for the rate growth of consumption are not statistically very robust.
} 
positively to the level of government debt. According to the results presented by those authors, there seems to be a statistically significant positive relation between public debt and the primary budget surplus, being therefore impossible to conclude that governments do not take into account their respective intertemporal budget constrainst. In other words, fiscal policy might have been implemented according to a Ricardian regime and therefore, these empirical results could not validate the FTPL hypothesis.

An approach similar to the one implemented by Mélitz (2000) is also adopted by Creel and Sterdyniak (2000), who mention that fiscal policy could be characterised by a Ricardian regime in Germany and in the US, and by a non-Ricardian regime in France. Additionally, another possible reading of the results presented by these two authors might be the conclusion that fiscal policy may have been, in the past, sustainable in Germany and not sustainable in France. ${ }^{15}$

\subsection{Some evidence for the EU-15}

The idea of implementing causality tests between real government debt and the real primary surplus, implied in the VAR models mentioned above, is not an easy approach to assess the possibility of the FTPL. In fact, both these variables are part of the present value borrowing constraint, a constraint that in the end holds true in any fiscal regime, either Ricardian or non-Ricardian. Since we are concerned with the EU-15 countries, a possible strategy might be to pool the data and use panel models along with some plausible testable assumptions.

In order to assess the possibility of the FTPL for the EU-15, panel data are used for the primary budget surplus, as a percentage of GDP, and for the debt-to-GDP ratio, between 1970 and $2001 .^{16}$ I use therefore 32 years of annual observations for 15 countries.

The existence of differences between the several countries is taken into account, by allowing that the autonomous term changes from country to country, in each cross-

\footnotetext{
${ }^{15}$ This is in fact one of the conclusions presented by Afonso (2000).

${ }^{16}$ The statistical sources are mentioned in the Annex.
} 
section sample, in order to capture those individual country characteristics. A tentative model is given by the following equation,

$$
S_{i t}=\beta_{i}+\delta S_{i t-1}+\theta B_{i t-1}+u_{i t}
$$

where $S$ is the primary surplus as a percentage of GDP, $B$ is the debt-to-GDP ratio, the index $i$ denotes the country, the index $t$ indicates the period and $\beta_{i}$ stands for the individual effects to be estimated for each country $i$, in order to test:

i) if $\theta=0$, the budget surplus does not react to the level of public debt, then the price level could be determined by the government budget constraint;

ii) if $\theta>0$, the government tries to increase the budget surplus in order to act in react to the existing stock of public debt and comply with the budget constraint, this could be seen as a sign of a regime of monetary dominance.

Table 2 reports the results regarding the estimation of equation (27). Notice that one can not reject the hypothesis $\theta>0$, since this coefficient is indeed statistically different from zero and positive. In other words, the EU-15 governments seem to act in accordance with the existing stock of public debt, by increasing the budget surplus as a result of increases in the outstanding stock of public debt. This is also consistent with a Ricardian regime, where fiscal policy adjusts to the intertemporal budget constraint, preventing for that reason the determination of the price level through the budget constraint.

The feasibility of the random effects model is assessed by the Hausman statistic, which tests the null hypothesis that the random effects are not correlated with the explanatory variables. In our case, and taking into account the fact that the test statistic is significant at the 1 per cent level, the random effects model hypothesis is rejected, in favour of the fixed effects model. 
Table 2 - Estimation of equation (27), dependent variable: primary surplus as a percentage of GDP $(S)$

\begin{tabular}{|l|c|c|c|}
\hline $\begin{array}{c}\text { Variable } \\
\text { (coefficient) }\end{array}$ & $\begin{array}{c}\text { Pooled } \\
\text { regression }\end{array}$ & $\begin{array}{c}\text { Fixed effects } \\
\text { model }\end{array}$ & $\begin{array}{c}\text { Random } \\
\text { effects model }\end{array}$ \\
\hline Constant $\left(\beta_{\mathrm{i}}\right)$ & $\begin{array}{c}-0,390 \\
(-2,488)\end{array}$ & & $\begin{array}{c}-0,704 \\
(-3,412)\end{array}$ \\
\hline$\delta\left(\mathrm{S}_{\mathrm{it}-1}\right)$ & $\begin{array}{c}0,885 \\
(39,363)\end{array}$ & $\begin{array}{c}0,792 \\
(29,870)\end{array}$ & $\begin{array}{c}0,839 \\
(34,338)\end{array}$ \\
\hline $\boldsymbol{\theta}\left(\mathrm{B}_{\mathrm{it}-1}\right)$ & $\begin{array}{c}0,011 \\
(4,556)\end{array}$ & $\begin{array}{c}0,030 \\
(7,969)\end{array}$ & $\begin{array}{c}0,019 \\
(6,305)\end{array}$ \\
\hline$-R^{2}$ & 0,7784 & 0,7950 & 0,7723 \\
\hline $\mathrm{F}^{2}$ test & & $\begin{array}{c}3,406^{*} \\
(14,428)\end{array}$ & \\
\hline Hausman $^{\mathrm{b}}$ test & & & $27.159 * *$ \\
& & & $(2)$ \\
\hline DW & 1,759 & 1,766 & 1,616 \\
\hline
\end{tabular}

The $t$ statistics are in parentheses.

a - The degrees of freedom for the F statistic are in parentheses; the statistic tests the fixed effects model against the pooled regression model, where the autonomous term is the same for all countries, which is the null hypothesis.

b - The statistic has a Chi-square distribution (the degrees of freedom are in parentheses); the Hausman statistic tests the fixed effects model against the random effects, which is here the null hypothesis.

* - Statistically significant at the 1 percent level, the null hypothesis of the pooled regression model is rejected.

** - Statistically significant at the 1 per cent level, the null hypothesis is rejected (random effects model), that is, one rejects the hypothesis that the autonomous terms in each country is not correlated with the independent explanatory variables (in this case the random effects model does not produce unbiased and consistent estimators).

Additionally, one may also try to estimate the following model

$$
B_{i t}=\alpha_{i}+\gamma S_{i t-1}+\varphi B_{i t-1}+v_{i t} \text {, }
$$

where $S$ is the primary surplus as a percentage of GDP, $B$ is the debt-to-GDP ratio, the index $i$ denotes the country, the index $t$ indicates the period and $\alpha_{i}$ stands for the individual effects to be estimated for each country $i$. One may then put forward the following ideas:

i) the hypothesis of a Ricardian regime, of monetary dominance, is not rejected when $\gamma<0$, most likely the government is using budget surpluses to reduce outstanding public debt; 
ii) with $\gamma \geq 0$, there might be a non-Ricardian regime, that is, a regime of fiscal dominance.

Table 3 reports the estimation results of equation (28). The possibility of the fixed effects model seems to get more statistical validation as one may confirm by the value of the F statistic. This is a test of the null hypothesis that all effects are the same for each country, in other words, the hypothesis that all autonomous terms $\alpha_{i}$ for equation (28) are identical. ${ }^{17}$

Table 3 - Estimation of equation (28), dependent variable: debt-to-GDP ratio $(B)$

\begin{tabular}{|l|c|c|c|}
\hline $\begin{array}{c}\text { Variable } \\
\text { (coefficient) }\end{array}$ & $\begin{array}{c}\text { Pooled } \\
\text { regression }\end{array}$ & $\begin{array}{c}\text { Fixed effects } \\
\text { model }\end{array}$ & $\begin{array}{c}\text { Random } \\
\text { effects model }\end{array}$ \\
\hline Constant $\left(\alpha_{\mathrm{i}}\right)$ & $\begin{array}{c}2,456 \\
(7,124)\end{array}$ & $\begin{array}{c}2,552 \\
(5,387)\end{array}$ \\
\hline$\gamma\left(\mathrm{S}_{\mathrm{it}-1}\right)$ & $\begin{array}{c}-0,618 \\
(-12,469)\end{array}$ & $\begin{array}{c}-0,766 \\
(-13,205)\end{array}$ & $\begin{array}{c}-0,716 \\
(-13,287)\end{array}$ \\
\hline$\varphi\left(\mathrm{B}_{\mathrm{it}-1}\right)$ & $\begin{array}{c}0,987 \\
(177,643)\end{array}$ & $\begin{array}{c}0,989 \\
(121,907)\end{array}$ & $\begin{array}{c}0,988 \\
(144,211)\end{array}$ \\
\hline$-R^{2}$ & 0,9862 & 0,9874 & 0,9860 \\
\hline $\mathrm{F}^{\text {a }}$ test & & $\begin{array}{c}3,904 * \\
(14,429)\end{array}$ & \\
\hline $\mathrm{Hausman}^{\mathrm{b}}$ test & & & $7.930 * *$ \\
& & & $(2)$ \\
\hline & 1,049 & 1,241 & 1,066 \\
\hline
\end{tabular}

The $t$ statistics are in parentheses.

a - The degrees of freedom for the F statistic are in parentheses; the statistic tests the fixed effects model against the pooled regression model, where the autonomous term is the same for all countries, which is the null hypothesis.

b - The statistic has a Chi-square distribution (the degrees of freedom are in parentheses); the Hausman statistic tests the fixed effects model against the random effects, which is here the null hypothesis.

* - Statistically significant at the 1 percent level, the null hypothesis of the pooled regression model is rejected.

** - Statistically significant at the 1 per cent level, the null hypothesis is rejected (random effects model), that is, one rejects the hypothesis that the autonomous terms in each country is not correlated with the independent explanatory variables (in this case the random effects model does not produce unbiased and consistent estimators).

\footnotetext{
${ }^{17}$ The F statistic is computed as $F(n-1, n T-n-k)=\left[\left(R_{u}{ }^{2}-R_{p}{ }^{2}\right) /\left(1-R_{u}{ }^{2}\right)\right][(n T-n-k) /(n-1)]$, where $u$ stands for the model without restrictions, $p$ denotes the pooled regression, that is the model with the restriction that there is only one autonomous term, $n$ is the number of countries, $T$ is the number of periods and $k$ is the number of exogenous variables (see for instance, Greene (1997) and Johnston and DiNardo (1997)).
} 
From the results presented above one may see that there is some evidence in favour of a Ricardian regime, of monetary dominance, and that the EU-15 governments have a tendency to use primary budget surplus to reduce the debt-to-GDP ratio, since we get a negative sign for the estimated $\gamma$ coefficient $(-0,766$, in the fixed effects model) for equation (28). There is therefore no evidence that can be regarded as supporting the FTPL for this set of European countries.

The fixed effects model is a typical choice for macroeconomists, and may eventually be more adequate than the random effects model. For instance, if the individual effects are somehow a substitute for non-specified variables, it is probable that each country specific effects are correlated with the other independent variables. In addition, and since the country sample includes all the relevant countries, the EU-15 countries, it is less obvious that one might want to consider this set of countries as a random sample of a larger universe of countries.

In other words, and as reminded by Greene (1997) and Judson and Owen (1997), when the individual observations sample (countries in our case) comes from a larger population (which could be instance all the developed countries), it would be suitable to consider the specific constant terms as randomly distributed through the cross section units. However, and even if the present country sample includes a small number of countries, it is sensible to admit that the EU-15 countries have similar specific characteristics, not shared by the other countries in the world. In this case, it would seem adequate to choose the fixed effects formalization, even if it is not correct to generalize the results afterwards, to the entire population, which is not the purpose of the paper.

In the previous specification there is nevertheless an implicit assumption that the underlying model is homogeneous that is, the coefficients are the same for all countries. As a matter of fact, one of the problems with panel data estimations, as mentioned namely by Haque, Pesaran and Shrama (2000), is the possibility of the real model might be heterogeneous, with different coefficients for the explanatory variables in the crosssection dimension. Assuming the same coefficients for all the countries, with the exception of the intercept, may give rise to non-linearity in the estimations, even if the relation between the variables is linear. An alternative estimator, proposed by Pesaran 
and Smith (1995), the mean group estimator, is based on the separate estimation of the coefficients for each cross-section unit, through the least squares method, and then computing the arithmetic mean of those coefficients. Still, this alternative procedure, does not allow for the hypothesis that some of the coefficients may indeed be the same for several countries.

Besides the problem mentioned above, and to circumvent the potential non-stationarity problem arising from the time-series dimension of the data, empirical models in the literature are usually estimated with the first differences of the variables. Even so, in most cases this procedure does not fully solve the problem. ${ }^{18}$ Also, the alternative of using variables in first differences might not take into account the fact that there is a levels relation between the government budget balance and the stock of outstanding public debt, through the present value borrowing constraint.

Another version of equation (28) was therefore estimated, using the first differences of the original variables

$$
b_{i t}=x_{i}+k s_{i t-1}+w b_{i t-1}+\varpi_{i t},
$$

where $x_{i}$ gives now the individual effects for each country $i$, and $b_{i t}=B_{i t}-B_{i t-1}$ and $s_{i t}=S_{i t^{-}}$ $S_{i t-1}$.

From the results results for the estimation of equation (29), presented in Table 4, one can draw some tentative additional conclusions. With the variables in first differences, both the pooled regression and the random effects models are chosen against the fixed effects model, since respectively the $\mathrm{F}$ and Hausman test statistics are not statistically significant. Also, the estimated coefficient $k$ for the primary surplus maintains its negative sign in all models. This can once more be seen as evidence against the validation of the FTPL hypothesis for EU-15 countries.

\footnotetext{
${ }^{18}$ Some papers dealing with the properties of estimators, and recent developments in panel unit root tests and cointegration tests in panel data models are, for example, Alvarez and Arellano (1998), Phillips and Moon (2000) and Arellano and Honoré (2001).
} 
Table 4 - Estimation of equation (29), dependent variable: first difference of the debt-to-GDP ratio $(b)$

\begin{tabular}{|c|c|c|c|}
\hline $\begin{array}{c}\text { Variable } \\
\text { (coefficient) }\end{array}$ & $\begin{array}{c}\text { Pooled } \\
\text { regression }\end{array}$ & $\begin{array}{c}\text { Fixed effects } \\
\text { model }\end{array}$ & $\begin{array}{c}\text { Random } \\
\text { effects model }\end{array}$ \\
\hline Constant $\left(\mathrm{x}_{\mathrm{i}}\right)$ & $\begin{array}{c}0,396 \\
(2,145)\end{array}$ & & $\begin{array}{c}0,398 \\
(2,057)\end{array}$ \\
\hline $\mathrm{k}\left(\mathrm{s}_{\mathrm{it}-1}\right)$ & $\begin{array}{c}-0,339 \\
(-3,543)\end{array}$ & $\begin{array}{c}-0,360 \\
(-3,708)\end{array}$ & $\begin{array}{c}-0,346 \\
(-3,645)\end{array}$ \\
\hline $\mathrm{w}\left(\mathrm{b}_{\mathrm{it}-1}\right)$ & $\begin{array}{c}0,594 \\
(15,299) \\
\end{array}$ & $\begin{array}{c}0,567 \\
(13,708) \\
\end{array}$ & $\begin{array}{c}0,586 \\
(15,103) \\
\end{array}$ \\
\hline $\bar{R}^{2}$ & 0,4077 & 0,3963 & 0,4077 \\
\hline $\mathrm{F}^{\mathrm{a}}$ test & & $\begin{array}{c}0,460 \\
(14,413)\end{array}$ & \\
\hline Hausman ${ }^{\mathrm{b}}$ test & & & $\begin{array}{c}2,557 \\
(2) \\
\end{array}$ \\
\hline DW & 2,083 & 2,068 & 2,068 \\
\hline
\end{tabular}

The $t$ statistics are in parentheses.

a - The degrees of freedom for the F statistic are in parentheses; the statistic tests the fixed effects model against the pooled regression model, where the autonomous term is the same for all countries, which is the null hypothesis.

b - The statistic has a Chi-square distribution (the degrees of freedom are in parentheses); the Hausman statistic tests the fixed effects model against the random effects, which is here the null hypothesis.

Also, it is possible to think of another test to assess empirically the FTPL. As already mentioned, the FTPL stresses the point that the price level could be determined by equation (25). For instance, if the government raises taxes then, according to that equation, there should be a price level decrease, resulting from the fact that the fiscal surplus is also higher. That is, if it is possible to observe a sustained negative correlation between prices and fiscal revenues one could conclude that there is in place a nonRicardian fiscal policy, supporting the idea of the FTPL. However, if there is instead a regime of monetary dominance, the price level should be independent from the evolution of the government revenues.

A possible specification to test the hypothesis mentioned above could be the following equation

$$
P_{i t}=\lambda_{i}+\omega_{p} P_{i t-1}+\omega_{R} R_{i t-1}+\varepsilon_{i t},
$$

where $P$ is the average annual change of the price deflator of private final consumption expenditure and $R$ is the first difference of total public receipts as a percentage of GDP. 
The results of the estimation of equation (30), reported in Table 5, show that the price level does not seem to have a statistically significant relation with the government revenues. This is true for the pooled regression, fixed effects and random effects versions, even though now the fixed effects model is not statistically better when compared against the other two versions. Furthermore, such a relation, even if significant at the 10 per cent level, is nevertheless positive, and not negative, as one would expect if the price level adjusted upwards after a decrease in public revenues. Therefore, one could hardly decide, with this evidence, for the validation of the FTPL in the EU-15 countries.

Table 5 - Estimation of equation (30), dependent variable: average annual change of the price deflator

\begin{tabular}{|c|c|c|c|}
\hline $\begin{array}{c}\text { Variable } \\
\text { (coefficient) }\end{array}$ & $\begin{array}{c}\text { Pooled } \\
\text { regression }\end{array}$ & $\begin{array}{c}\begin{array}{c}\text { Fixed effects } \\
\text { model }\end{array} \\
\end{array}$ & $\begin{array}{c}\text { Random } \\
\text { effects model }\end{array}$ \\
\hline Constant $\left(\lambda_{\mathrm{i}}\right)$ & $\begin{array}{c}0,650 \\
(3,361)\end{array}$ & & $\begin{array}{c}-0,704 \\
(-3,412)\end{array}$ \\
\hline$\omega_{\mathrm{P}}\left(\mathrm{P}_{\mathrm{it}-1}\right)$ & $\begin{array}{c}0,892 \\
(41,741)\end{array}$ & $\begin{array}{c}0,850 \\
(33,411)\end{array}$ & $\begin{array}{c}0,878 \\
(39,186)\end{array}$ \\
\hline$\omega_{\mathrm{R}}\left(\mathrm{R}_{\mathrm{it}-1}\right)$ & $\begin{array}{l}0,175^{*} \\
(1,713) \\
\end{array}$ & $\begin{array}{l}0,187^{*} \\
(1,800)\end{array}$ & $\begin{array}{l}0,179^{*} \\
(1,774)\end{array}$ \\
\hline$R^{2}$ & 0,8029 & 0,8008 & 0,8029 \\
\hline $\mathrm{F}^{\mathrm{a}}$ test & & $\begin{array}{c}0,683 \\
(14,439)\end{array}$ & \\
\hline Hausman $^{\mathrm{b}}$ test & & & $\begin{array}{c}5.601 * * \\
(2)\end{array}$ \\
\hline DW & 1,789 & 1,754 & 1,762 \\
\hline
\end{tabular}

The $t$ statistics are in parentheses.

$\mathrm{a}$ - The degrees of freedom for the $\mathrm{F}$ statistic are in parentheses; the statistic tests the fixed effects model against the pooled regression model, where the autonomous term is the same for all countries, which is the null hypothesis.

b - The statistic has a Chi-square distribution (the degrees of freedom are in parentheses); the Hausman statistic tests the fixed effects model against the random effects, which is here the null hypothesis.

* - Statistically significant at the 10 per cent level.

** - Statistically significant (only) at the 10 per cent level, the null hypothesis is rejected (random effects model), that is, one rejects the hypothesis that the autonomous terms in each country are not correlated with the independent explanatory variables (in this case the random effects model does not produce unbiased and consistent estimators). 


\section{Conclusion}

The FTPL, credited mainly to the work of LSW, confers the government budget constraint a key role in determining the price level. This is a relatively recent subject in macroeconomics, nevertheless with increasing discussions in the literature. The more active supporters of the theory (namely Woodford, Sims and Cochrane) argue that in a non-Ricardian fiscal regime, the price level is determined by the ratio between nominal public debt (or the government liabilities) and the present value of future primary fiscal surpluses (including possible seigniorage revenues). The criticisms of the FTPL appear to be more intense when the Central Bank decides to adopt an active strategy in determining the nominal interest rate.

As many new topics and theories in economics, this is a rather controversial issue since it directly questions the ability of monetary policy and of the quantitative theory of money to explain and determine the price level. There are therefore already several papers opposing this discussion of the monetary ortodoxy, being worthwile to mention again McCallum and Buiter among the more hard-hearted critics.

Probably the main contribution of the FTPL, in its criticism of the quantitative theory of money, is to discuss if the the price level may be determined, in part, and under some given conditions, by fiscal policy. However, to distinguish between if the supply of money and the interest rate are determined by fiscal policy or if the money supply and interest rate are determined exogenously, it is not an easy point to assess either theoretically or empirically. All in all, the theoretical assumptions required for the existence of non-Ricardian regimes, where fiscal policy is actively determining the price level, regardless of monetary policy, seem rather tricky to agree with.

Concerning the empirical assessment of the FTPL, the very few papers that atempted that validation (for the US and for some OECD countries), with VAR models, conclude for the existance of regimes of monetary dominance. This paper adds to the literature by tentatively trying to test with panel data models, the feasibility of the FTPL for the EU15 countries. The results for the period 1970-2001 show, however, that the data allow the rejection of the testable hypothesis used to validate the FTPL, since for instance, the EU-15 governments have a tendency to use primary budget surplus to reduce the debt- 
to-GDP ratio. In other words, the FTPL does not seem to fit the EU-15, even if one were to endorse its theoretical framework.

\section{Annex - statistical sources}

- Net lending (+) or net borrowing (-) excluding interest payments of general government (Percentage of gross domestic product at market prices). AMECO Code: 1.0.310.0.UBLGI.

- Public debt; ESA 95; Maastricht and former definition (linked series) (Percentage of gross domestic product at market prices). AMECO Code: 1.0.310.0.UDGGL.

- Total public receipts (Percentage of gross domestic product at market prices). AMECO Code: 1.0.310.0.UTCTF.

- Price deflator of private final consumption expenditure. National currency. Index number. AMECO Code: 3.1.0.0.PCPH.

Source: AMECO (ANNUAL MACRO ECONOMIC DATABASE): European Commission, Directorate General, Economic and Financial Affairs, Directorate A: Economic studies and research; Unit 2: Economic databases and statistical coordination; Sector: Macro-economic database, November 2001.

\section{References}

Afonso, A. (2000). "Fiscal policy sustainability: some unpleasant European evidence," ISEG-UTL, Economics Department, Working Paper 12/2000/DE/CISEP.

Aiyagari. S. and Gertler, M. (1985). "The Backing of Government Bonds and Monetarism," Journal of Monetary Economics, 16 (1), 19-44.

Alvarez, J. and Arellano, M. (1998). "The Time Series and Cross-Section Asymptotics of Dynamic Panel Data Estimators,” Working Paper 9808 CEMFI, Madrid.

Andrés, J; Ballabriga, F. and Vallés, J. (2000). "Monetary Policy and Exchange Rate Behaviour in the Fiscal Theory of the Price Level," Banco de Espanha, Documento de Trabajo 0004.

Arellano, M. and Honoré, B. (2001) "Panel Data Models: Some Recent Developments," in Heckman, J. and Leamer, E. (eds.) Handbook of Econometrics, Volume 5, Elsevier.

Auernheimer, L. and Contreras, B. (1991). "A Nominal Interest Rate Rule: the Case of the Open Economy," mimeo, Texas A\&M University, July.

Bassetto, M. (2001). "A Game-Theoretic View of the Fiscal Theory of the Price Level," Federal Reserve Bank of Minneapolis, Working Paper 612, March.

Begg, D. and Haque, B. (1984). "A Nominal Interest Rate Rule and Price Level Indeterminacy Reconsidered," Greek Economic Review, 6 (1), 31-46. 
Bénassy, J-P. (2000). "Price Level Determinacy under a Pure Interest Rate Peg," Review of Economic Dynamics, 3 (1), 194-211.

Bergin, P. (2000). "Fiscal Solvency and Price level Determination in a Monetary Union," Journal of Monetary Economics, 45 (1), 37-53.

Blanchard, O. and Fischer, S. (1989). Lectures on Macroeconomics. MIT Press.

Bohn, H. (1999). "Comment," in Bernanke, B. and Rotemberg, J. (eds.), NBER Macroeconomics Annual 1998, 384-389.

Brock, W. (1975). “A Simple Perfect Foresight Monetary Model," Journal of Monetary Economics, 1, 133-150.

Buiter, W. (1998). "The Young Person's Guide to Neutrality, Price Level indeterminacy, Interest Rate Pegs and Fiscal Theories of the Price Level," CEPR Discussion Paper 1799, February.

Buiter, W. (1999). "The Fallacy of the Fiscal Theory of the Price Level," NBER Working Paper 7302, August.

Buiter, W. (2001). "The Fallacy of the Fiscal Theory of the Price Level, Again," Bank of England, Working Paper 141, July.

Cagan, P. (1956). "The Monetary Dynamics of Hyperinflation," in Friedman, M. (ed.), Studies in the Quantity Theory of Money, CUP.

Canzoneri, M. and Diba, B. (1999). "The stability and Growth Pact: a Delicate Balance or an Albatross?" Empirica, 26 (3), 241-258.

Canzoneri, M.; Cumby, R. and Diba, B. (1997). "Does Monetary or Fiscal Policy Provide a Nominal Anchor? Evidence from the OECD Countries," mimeo.

Canzoneri, M.; Cumby, R and Diba, B. (2000). "Is the Price Level Determined by the Needs of Fiscal Solvency?" forthcoming in American Economic Review.

Canzoneri, M.; Cumby, R. and Diba, B. (2001). "Fiscal Discipline and Exchange Rates Systems," Economic Journal, 111 (474), 667-690.

Carlstrom, C. and Fuerst, T. (2000). "The fiscal theory of the price level," Federal Reserve Bank of Cleveland Economic Review, 1st trimestre, 22-32.

Carlstrom, C. and Fuerst, T. (2001). "Real Indeterminacy in Monetary Models with Nominal Interest Rate Distortions," Review of Economic Dynamics, 4 (4), 767-789.

Christiano, L. and Fitzgerald, T. (2000). "Understanding the fiscal theory of price level," Federal Reserve Bank of Cleveland. Economic Review, $2^{\circ}$ trimestre, 2-38.

Cochrane, J. (1999). "A Frictionless View of U.S. Inflation," in Bernanke, B. and Rotemberg, J. (eds.), NBER Macroeconomics Annual 1998, 323-384. 
Cochrane, J. (2000). "Money as Stock: Price Level Determination with no Money Demand," NBER Working Paper 7498, January.

Cochrane, J. (2001). "Long-term Debt and Optimal Policy in the Fiscal Theory of the Price Level," Econometrica, 69 (1), 69-116.

Corsetti, G. and Mackowiak, B. (2000). "Nominal debt and the dynamics of currency crisis," Economic Growth Center Discussion Paper 820, Yale University.

Creel, J. and Sterdyniak, H. (2000). "La théorie budgetaire du niveau des prix: un bilan critique," OFCE, document de travaille 2000-3, November.

Cushing, M. (1999). "The indeterminacy of prices under interest rate pegging: The nonRicardian case," Journal of Monetary Economics, 44 (1), 131-148.

Daniel, B. (2001). "The Fiscal Theory of the Price Level in an Open Economy," Journal of Monetary Economics, 48 (2), 293-308.

Debrun, X. and Wyplosz, C. (1999). "Onze gouvernments et une Banque centrale," Revue d' Economie Politique, 3, 387-420.

Dupor, W. (2000). "Exchange Rates and the Fiscal Theory of the Price Level," Journal of Monetary Economics, 45 (3), 613-630.

Dwyer, G. and Hafer, R. (1999). "Are Money Growth and Inflation Still Related?" Federal Reserve Bank of Atlanta Economic Review, 84 (2), 32-43.

Fisher, I. (1911). The Purchasing Power of Money, Augustus M. Kelley, Publishers, 1985.

Greene, W. (1997). Econometric Analysis, 3ª ed., Prentice Hall.

Haque, N.; Pesaran, M. and Sharma, S. (2000). "Neglected Heterogeneity and Dynamics in Cross-Country Savings Regressions," in Krishnakumar, J. and Ronchetti, E. (eds.), Panel Data Econometrics: Future Directions: Papers in Honour of Professor Pietro Balestra, Elsevier.

Hetzel, R. and Leach, R. (2001). "The Treasury-Fed Accord: A New Narrative Account," Federal Reserve Bank of Richmond Economic Quarterly, 87 (1), 33-55.

Johnston, J. and DiNardo, J. (1997). Econometric Methods, 4th ed., McGrawHill.

Judson, R. and Owen, A. (1997). "Estimating Dynamic Panel Data Models: A Practical Guide for Macroeonomists," Finance and Economics Discussion Papers 1997-3, Federal Reserve System.

Kenc, T.; Perraudin, W. and Vitale, P. (2000). "Inflation and Sovereign Default," IMF Staff Papers, 47 (3), 366-386. 
Kocherlakota, N. and Phelan. C. (1999). "Explaining the Fiscal Theory of the Price Level," Federal Reserve Bank of Minneapolis Quarterly Review, 23 (4), 14-23.

Leeper, E. (1991). "Equilibria Under 'Active' and 'Passive' Monetary and Fiscal Policies," Journal of Monetary Economics, 27 (1), 129-147.

Loyo, E. (2000). "Tight Money Paradox on the Loose: A fiscalist Hyperinflation," mimeo, J. F. Kennedy School of Government.

Mélitz, J. (2000). "Some Cross-Country Evidence about Fiscal Policy Behaviour and Consequences for EMU," European Economy, Reports and Studies 2, 3-21.

McCallum, B. (1989). Monetary Economics: Theory and Policy, Macmillan Publishing Company.

McCallum, B. (1999a). "Issues in the Design of Monetary Policy Rules," in Taylor, J. and Woodford, M. (eds.), Handbook of Macroeconomics, North-Holland Pub. Co.

McCallum, B. (1999b). "Theoretical Issues Pertaining to Monetary Unions," NBER Working Paper 7393, October.

McCallum, B. (2001). "Indeterminacy, Bubbles, and the Fiscal Theory of Price Level Determination," Journal of Monetary Economics, 47 (1), 19-30.

Pesaran, M. and Smith, R. (1995). "Estimating Long-Run Relationships from Dynamic Heterogeneous Panels," Journal of Econometrics, 68 (1), 79-113.

Phillips, P. and Moon, H. (2000). "Nonstationary panel data analysis: an overview of some recent developments," Econometric Reviews 19 (3), 263-286.

Romer, D. (2000). "Keynesian Macroeconomics without the LM curve," Journal of Economic Perspectives, 14 (2), 149-169.

Sargent, T. (1982). "The Ends of Four Big Inflations," in Hall, R. (ed.), Inflation, University of Chicago Press.

Sargent, T. and Wallace, N. (1975). "'Rational' expectations, the optimal monetary instrument and the optimal money supply rule", Journal of Political Economy, 83 (2), 241-254.

Sargent, T. and Wallace, N. (1981). "Some Unpleasant Monetarist Arithmetic", Federal Reserve Bank of Minneapolis Quarterly Review, 5, 1-17.

Schmitt-Grohé, S. and Uribe, M. (2000). "Price Level and Determinacy and Monetary Policy under a Balanced-Budget Requirement," Journal of Monetary Economics, 45 (1), 211-246.

Sidrauski, M. (1967). "Rational Choice of Patterns of Growth in a Monetary Economy," American Economic Review, 57 (2), 534-544. 
Sims, C. (1994). "A Simple Model for the Study on the Determination of the Price Level and the Interaction of Monetary and Fiscal Policy," Economic Theory, 4 (3), 381399.

Sims, C. (1997). "Fiscal Foundations of Price Stability in Open Economies," Technical Report, Princeton University. [available at http://www.princeton.edu/ sims/.]

Sims, C. (1999). "The Precarious Fiscal Foundations of EMU," De Nederlandsche Bank Staff Reports 34.

Sims, C. (2001). "Fiscal Consequences for Mexico of Adopting the Dollar," Journal of Maoney, Credit, and Banking, 33 (2), parte 2, 617-625.

Wicksell, K. (1898), [1965]. Interest and Prices. Augustus M. Kelley, Pub., New York, Reprints of Economic Classics.

Wicksell, K. (1907). "The Influence of the Rate of Interest on Prices," Economic Journal, 17 (66), 213-220.

Woodford, M. (1994). "Monetary Policy and Price Level Determinacy in a Cash-inAdvance Economy," Economic Theory, 4 (3), 345-380.

Woodford, M. (1995). "Price Level Determinacy without Control of Monetary Aggregate," Carnegie-Rochester Conference Series on Public Policy, 43 (1), 1-46.

Woodford, M. (1996). "Control of the Public Debt: A Requirement for Price Stability?" NBER Working Paper 5684, July.

Woodford, M. (1998a). "Doing without Money: Controlling Inflation in a PostMonetary World," Review of Economic Dynamics, 1 (1), 173-219.

Woodford, M. (1998b). "Public Debt and the Price Level," mimeo, Princeton University, June.

Woodford, M. (1999). "Comment on Cochrane," in Bernanke, B. and Rotemberg, J. (eds.), NBER Macroeconomics Annual 1998, 390-419.

Woodford, M. (2001). "Fiscal Requirements for Price Stability," Journal of Money, Credit and Banking, 33 (3), 669-728. 